July 2015

\title{
A Call to Forward-Thinking Bioethics
}

Heather G. Kuruvilla

Cedarville University

Follow this and additional works at: http://digitalcommons.cedarville.edu/

bioethics_in_faith_and_practice

Part of the Bioethics and Medical Ethics Commons

DigitalCommons@Cedarville provides a publication platform for fully open access journals, which means that all articles are available on the Internet to all users immediately upon publication. However, the opinions and sentiments expressed by the authors of articles published in our journals do not necessarily indicate the endorsement or reflect the views of DigitalCommons@Cedarville, the Centennial Library, or Cedarville University and its employees. The authors are solely responsible for the content of their work. Please address questions to dc@cedarville.edu.

\section{Recommended Citation}

Kuruvilla, Heather G. (2015) "A Call to Forward-Thinking Bioethics," Bioethics in Faith and Practice: Vol. 1 : No. 1 , Article 2. DOI: $10.15385 /$ jbfp.2015.1.1.2

Available at: http://digitalcommons.cedarville.edu/bioethics_in_faith_and_practice/vol1/iss1/2 


\section{A Call to Forward-Thinking Bioethics}

Browse the contents of this issue of Bioethics in Faith and Practice.

\section{About the Author(s)}

Dr. Heather Kuruvilla is the Managing Editor of Bioethics in Faith and Practice and a Fellow of the Center for Bioethics at Cedarville University.

\section{Institution/Affiliation}

Cedarville University

\section{Abstract}

It is said that hindsight is always $20 / 20$. However, a reasoned approach to practical bioethics requires an awareness of developing technologies and their potential applications to clinical practice.

\section{Keywords}

Genetic ethics, biotechnology, CRISPR

\section{Creative Commons License}

\section{(c) (i) @ $\Theta$}

This work is licensed under a Creative Commons Attribution-Noncommercial-No Derivative Works 4.0

License. 


\title{
From the Managing Editor
}

\section{A Call to Forward-Thinking Bioethics}

\author{
Heather G. Kuruvilla, Ph.D. \\ Cedarville University
}

It is said that hindsight is always 20/20. However, a reasoned approach to practical bioethics requires an awareness of developing technologies and their potential applications to clinical practice. As a recent example, the powerful gene editing technology, CRISPR/Cas 9 has been widely used in the laboratory both to repair genetic defects and to disrupt gene expression. When Liang et al. ${ }^{1}$ published their study on April 18, which used CRISPR to edit non-viable human zygotes, a firestorm of debate ensued.

The data obtained by Liang et al. indicate a low editing efficiency in the embryos, as well as a high number of off-target mutations. ${ }^{2}$ As reported to Nature, one of the scientists in the study, Dr. Huang, noted, "That's why we stopped [the research]. It [the technology is] is still too immature."3

Other scientists remain convinced that such research on the human germline should not be allowed at present. For example, Lanphier and his colleagues, who use CRISPR to modify somatic cells, believe that using CRISPR on germ-line cells could have unpredictable, potentially harmful effects on future generations of human beings. ${ }^{4}$ However, they cite several examples of CRISPR-based somatic cell therapies in various stages of development, including a treatment for $\beta$-thassalemia that is scheduled to begin phase I trials later this year. ${ }^{5}$

While using genetically modified somatic cells certainly raises concerns of safety and efficacy, those concerns are limited to the individual being treated. Our current protocols for clinical trials are designed to address such questions. But the possibility of causing heritable genetic damage remains one of the major reasons that many nations, including the US, ban research that modifies the human germline.

The technical difficulties encountered by Liang and colleagues open up the floor for meaningful bioethical discussion. Now is the time to address deep issues of what it means to be human. Are concerns about modifying the human germline simply limited to safety and efficacy? If so, such concerns will likely be resolved as technology improves. And the technology is likely to improve quickly, as other scientists continue this research and perfect their protocols. Nature news writer David Cyranoski noted in his March $18^{\text {th }}$ article that several research teams are nearing publication of work similar to the study published by Liang et al. ${ }^{6}$

However, beyond the safety concerns lie deeper questions. Certainly the ability to edit the genome brings with it all kinds of therapeutic possibilities. At the same time, there is no reason why someone could not use this technology to modify the human species, with good or evil intent. Our genetics are an integral part of what make us human. We now hold tools which would allow modification of the human genome

Bioethics in Faith and Practice vol. 1, no. 1, pp. 1-2. ISSN 2374-1597

(c) 2015, Heather Kuruvilla, licensed under CC BY-NC-ND

(http://creativecommons.org/licenses/by-nc-nd/4.0/) 
on a much faster time frame than we have ever observed in nature. If we believe that modification of the human genome should be restricted to therapeutic uses, or even banned altogether, now is the time to frame those arguments. Now is the time for theoreticians and pragmatists to join forces, talk through the issues, and set policies. Regulations and laws need to be passed before embryonic human lives are irreversibly impacted.

How does our use of genetic technology impact us as human persons, and as a biological species? The window for discussion of these issues is closing as the technology continues to progress. It is time to speak up, or forever hold our peace.

${ }^{1}$ Liang, Puping, Yanwen Xu, Xiya Zhang, Chenhui Ding, Rui Huang, Zhen Zhang, Jie Lv, Xiaowei Xie, Yuxi Chen, Yujing Li, Ying Sun, Yaofu Bai, Zhou Songyang, Wenbin Ma, Canquan Zhou, and Junjiu Huang. "CRISPR/Cas9-mediated Gene Editing in Human Tripronuclear Zygotes." Protein \& Cell Protein Cell 6, no. 5 (2015): 363-72. Accessed July 15, 2015. doi: http://dx.doi.org/10.1007/s13238-015-0153-5.

${ }^{2}$ Ibid.

${ }^{3}$ Cyranoski, David, and Sarah Rearden. "Chinese Scientists Genetically Modify Human Embryos." Nature.com. April 22, 2015. Accessed July 15, 2015.

${ }^{4}$ Lanphier, Edward, Fyodor Urnov, Sarah Haecker, Michael Werner, and Joanna Smolenski. "Don't Edit the Human Germline." Nature.com. March 12, 2015. Accessed July 15, 2015.

${ }^{5}$ Ibid.

${ }^{6}$ Cyranoski, David. "Ethics of Embryo Editing Divides Scientists." Nature.com. March 18, 2015. Accessed July 15, 2015. 


\section{Bibliography}

Liang, Puping, Yanwen Xu, Xiya Zhang, Chenhui Ding, Rui Huang, Zhen Zhang, Jie Lv, Xiaowei Xie, Yuxi Chen, Yujing Li, Ying Sun, Yaofu Bai, Zhou Songyang, Wenbin Ma, Canquan Zhou, and Junjiu Huang. "CRISPR/Cas9-mediated Gene Editing in Human Tripronuclear Zygotes." Protein \& Cell Protein Cell 6, no. 5 (2015): 363-72. Accessed July 15, 2015. doi: http://dx.doi.org/10.1007/s13238-015-0153-5 .

Cyranoski, David, and Sarah Rearden. "Chinese Scientists Genetically Modify Human Embryos." Nature.com. April 22, 2015. Accessed July 15, 2015.

Lanphier, Edward, Fyodor Urnov, Sarah Haecker, Michael Werner, and Joanna Smolenski. "Don't Edit the Human Germline." Nature.com. March 12, 2015. Accessed July 15, 2015.

Cyranoski, David. "Ethics of Embryo Editing Divides Scientists." Nature.com. March 18, 2015. Accessed July 15, 2015. 